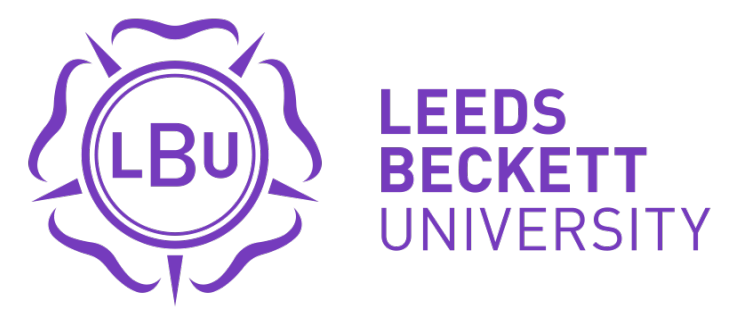

Citation:

Spracklen, K and Henderson, S (2013) "Oh! What a tangled web we weave": Englishness, communicative leisure, identity work and the cultural web of the English folk morris dance scene. Leisure/ Loisir, 37 (3). 233 - 249. ISSN 1492-7713 DOI: https://doi.org/10.1080/14927713.2013.848552

Link to Leeds Beckett Repository record:

https://eprints.leedsbeckett.ac.uk/id/eprint/214/

Document Version:

Article (Accepted Version)

The aim of the Leeds Beckett Repository is to provide open access to our research, as required by funder policies and permitted by publishers and copyright law.

The Leeds Beckett repository holds a wide range of publications, each of which has been checked for copyright and the relevant embargo period has been applied by the Research Services team.

We operate on a standard take-down policy. If you are the author or publisher of an output and you would like it removed from the repository, please contact us and we will investigate on a case-by-case basis.

Each thesis in the repository has been cleared where necessary by the author for third party copyright. If you would like a thesis to be removed from the repository or believe there is an issue with copyright, please contact us on openaccess@leedsbeckett.ac.uk and we will investigate on a case-by-case basis. 
Manuscript: LL-13.032

Re-submission

\title{
'Oh! What a Tangled Web We Weave': Englishness, communicative leisure, identity work and the cultural web of the English folk morris dance scene
}

\begin{abstract}
In this paper, we consider the relationship between Englishness and the English folk morris dance scene, considering how the latter draws from and reinforces the former. Englishness is considered within the context of the cultural web; a tool more often applied to business management but linked to a sociological viewpoint here. By doing so, we draw the connections between this structured business model and the cultural identity of Englishness. Then, we use the framework of the cultural web and theories of leisure, culture and identity to understand how morris dancers see their role as dancers and 'communicative leisure' agents in consciously defending Englishness, English traditions and inventions, the practices and traditions of folk and morris, and the various symbolic communities they inhabit. We argue that most morris dancers in our research become and maintain their leisured identities as dancers because they are attracted to the idea of tradition - even if that tradition is invented and open to change.
\end{abstract}

Key words: communicative leisure, culture, Englishness, morris. 
'Oh! What a Tangled Web We Weave': Englishness, communicative leisure, identity work and the cultural web of the English folk morris dance scene

\section{Introduction}

As iconic symbols of national culture, opening and closing ceremonies of the Olympic Games and other global events are important to host nations and their populations: they re-construct national stereotypes, confirm narratives of belonging and (re)produce symbols and myths that the event organizers wish to associate with the host nation (Lenskyj, 2000). In these ceremonies, host nations typically identify folk cultures, folk dances and music associated with their countries, utilizing the ceremonies to demonstrate the things they want outsiders to associate with them: narrow ethnic nationalism, communist pride and ingenuity, imperialist bluster or contrived folksiness (Spracklen, 2013a). Such ceremonies, then, become spaces of imagined and imaginary community, shaped by normative discourses but co-opting new notions of belonging and identity. In the summer of 2012, the version of England celebrated in the opening ceremony of the London Olympics presented an England subsumed in a Great Britain of multiculturalism and culturally cool icons, comfortable with its Queen and its English fields, but also proud of its industry and its National Health Service. In trying to make England a part of a postmodern Great Britain, a United Kingdom in a globalized society, the opening ceremony missed the opportunity to highlight English folk traditions.

One such folk tradition was morris dancing. Morris is a form of folk dance performed in group formations accompanied by traditional English folk tunes played live by musicians ${ }^{1}$. The dances have steps fixed by the rules of the official books of steps written by members of the Morris Ring (the official organization of morris) and the English Folk Dance and Song Society. There has been a long debate in "the morris” about the inclusion of women in morris sides (Jefferies and Tyldesley, 2011). Originally, the revivalists insisted morris was an all-male preserve, and this remained the policy of the Morris Ring until the last quarter of the twentieth century (the gender bias led to the launch of the Morris Federation, which is more inclusive). Even now, most morris dancing is all-male, and sides that are female, or that have mixed dancing, might fail to be invited to dance with more traditionally-minded men's sides.

\footnotetext{
${ }^{1}$ Groups of morris dancers along with their musicians are known as sides.
} 
There is a range of styles within morris, but the main ones are Cotswold (in which dancers wear white and use hankies) and Border (where dancers use sticks and often wear masks or blacken their faces). Most morris dancers use bells attached to leggings or shoes to make a noise when they move.

In England, folk revivals became popular following the publication of Frazer's The Golden Bough: A Study in Magic and Religion (2004[1890]). His richlyevidenced book persuaded many people in England to seek out the remnants of folk leisure in far-off villages. Some people decided to record songs sung by travellers and others living in rural places, with suitable removals of modern influences from the music hall (Francmanis, 2002). Books were published about dances and sports that had survived industrialization, such as the so-called folk football games of Ashbourne or Workington, or the hobby-horses of Padstow, which were said to be pagan in origin (Hutton, 2006). Others read local histories to try to find traditions that had died out, and which might be revived. This led to the (re)construction of English folk dance in the form of morris and mummery plays ${ }^{2}$, a process that continued through the twentieth century.

Before the London 2012 Olympics, a palpable anger and indignation was shown by morris dancers who saw their possible absence from the official ceremonies of the London 2012 Olympics as an affront to their "Englishness” (Condron, 2011). However, perhaps because of their campaigns to try to get morris included in the official ceremonies, morris dancers did appear briefly in the closing ceremony of London 2012. Morris dancing, then, plays a contested role in popular cultural notions of Englishness. Morris dance is part of English national folk culture, and English popular culture, but it is seen as something culturally residual (Williams, 1981). It is loved and regaled in equal measures. Every weekend in the summer, one can find hundreds of morris sides out dancing across England. Some of these sides dance in typically English villages, but others just as likely in town squares and city streets where there are nearby pubs and potential audiences. Many popular misconceptions of morris associate the dancing with people that are somehow 'uncool' or unfashionable. Morris dancing and its dancers are targets of jokes in well-known television

\footnotetext{
${ }^{2}$ Mummery plays were traditionally performed at holidays, and involved Saint George defeating all his enemies. In the revival they have come to include more contemporary themes. They are often performed alongside morris dances by specialist mummers.
} 
programmes such as the Blackadder comedy series ${ }^{3}$, and it is still common to read journalists mocking morris dancing as an inauthentic, irrelevant practice. At the same time, far-right political parties such as the British Nationalist party (BNP) have attempted to co-opt morris dancing and English folk music as an authentic white English tradition that needs to be protected and celebrated (Featherstone, 2009; Spracklen, 2013b). For English nationalists, morris dancing is part of a narrowly defined Englishness that promotes whiteness and racialization under a loosely defined banner of English ethnicity. In other words, the language used by supporters of English folk traditions becomes co-opted by such racist ideologies, and the English become a folk to be preserved from the evils of modernity such as globalisation and multiculturalism. Under such pressure, it is not surprising that the London 2012 organizers were seemingly wary of involving morris dancing in the official ceremonies.

This paper is part of a wider project exploring the English folk scene. In this paper, we explore the everyday leisure practice and spaces of English morris dancing (LeFevbre, 1991[1947]). In doing so we will explore how identity works in the 'communicative leisure' space of morris dancing creates Englishness and other identities, and discover how English morris dancers negotiate meaning and community in morris dancing. Englishness expressed in morris dancing is considered within the context of the cultural web (Seel, 2000), which draws on the work of Geertz (1973) and Goffman (1971). By doing so, we draw the connections between this structured business model and the cultural identity of Englishness. We use this model to understand how morris dancers see their role as dancers and 'communicative leisure' agents in consciously or defending Englishness, English traditions and inventions, the practices and traditions of folk and morris, and the various symbolic communities they inhabit.

\section{Literature Review}

\section{Communicative Leisure and Dancing as Leisure}

Communicative rationality is identified by Habermas (1981) as the free interchange of ideas based on mutual respect, the application of reason and democracy, and the

\footnotetext{
${ }^{3}$ See also the 2009 comedy film Morris: A Life With Bells On (dir. Lucy Akhurst) for a supposedly sympathetic take on English morris, but one which perpetuates the stereotypes of uncool people being unironic in their obsession about the dance.
} 
existence of a public sphere in which such freedoms are protected and maintained. Communicative rationality leads to communicative actions and the formation of what Habermas (1981) calls the lifeworld, the everyday space where we can be free and equal as interacting humans. As something supposedly done freely, leisure in theory is a communicative action. Habermas (1981) notes leisure's potential in the formation of the lifeworld, but he is also aware that leisure is something that is easily made un-free, a product of what he calls the instrumentality of modern capitalism and nation-state bureaucracies. Spracklen $(2009,2011,2013 a)$ uses Habermas to construct a definitional framework of leisure bounded by communicative and instrumental leisure. Communicative leisure is freely made leisure, and instrumental leisure is given or sold to people to keep them in the grip of hegemonic control. For Spracklen, leisure is a universal human desire, an activity and space that allows humans to explore their humanity and their sociality. Communicative leisure is leisure that is freely constructed, which has meaning for its participants and allows for the construction and preservation of the lifeworld. Where leisure is communicative it is engaged and potentially a site for the development of equality and cosmopolitanism, but at all times there is a threat to the 'purity' of leisure from the instrumentality of capitalism and other hegemonic powers. Habermas' pessimism does not rule out leisure and culture being places where communicative rationality can produce communicative action, only that to be communicative, there has to be a public (externalized) sphere in which debates about meaning can take place. Leisure can only be morally instructive if it plays a communicative role, or is the product of such communicative rationality. Where leisure is a product of consumption and commodification, the end-point of some instrumentally rational system, such as global capitalism, it becomes less useful as a space, form or activity that gives individuals meaning and purpose.

Leisure researchers have started to examine dancing as a leisure activity (Critcher, 2000; Irving \& Giles, 2011; Jaimangal-Jones, Pritchard \& Morgan, 2002; Urquia, 2005 - see also studies from cultural sociology such as Kolb, 2013). There is nothing seemingly more communicative than dancing. People choose to dance because they like dancing as a leisure activity and feel the activity gives them some sense of self-identity and satisfaction (Urquia, 2005). Dancing creates a sense of community and belonging (Irving \& Giles, 2011), a safe leisure space for people to gather and socialize. Of course, such leisure spaces and activities are not pure 
communicative leisure experiences. Dancing is often constrained as a leisure practice, denied to people because of gender or class or some other social status, or marginalized because a particular form of dance is not perceived as high culture (Kolb, 2013). Dancing as a leisure practice is often the product of moral panics about juvenile delinquency (Critcher, 2000).

Nightclubs and gig venues offer people the opportunity to dance and to feel a sense of the liminal, a sense of communitas and belonging (Turner, 1969). But such places can have negative, instrumental connotations (Critcher, 2000). They can be commercial spaces designed to rob drunk and vulnerable people of their money through over-priced drinks and entry fees. Musicians and DJs know the combinations of sounds that can move us, the heavy bass notes that tingle in our stomachs, and the key changes that make us smile and wave our hands in the air, and the rhythms that move our bodies. In these liminal spaces of leisure, we can truly express ourselves, feel at one with others, and find some meaning and purpose. Gigs and nightclubs are of course commercial transactions (Habermas, 1981). In pre-modernity, people sang and played music for themselves, while others danced to that music (Spracklen, 2011), but finding a public or private space where this happens is a rare thing in late modernity (Dudrah, 2011). Morris dancing is communicative leisure because it is voluntary, free and meaningful for its participants.

\section{Englishness}

Englishness, like any national brand or national ideology, remains an individual perception that, at best, might be summarised as some kind of averaged viewpoint, a collection of stereotypes and myths. Englishness becomes something about the English past, but also something about the manners and cultural practices associated with the English (by themselves and by those on the outside looking in). So, for example, English people are stereotyped by Americans as living in land of bad teeth and cockneys who doff their cap to the Queen; and the French see the English as stuffed fat with roast beef ${ }^{4}$. The English themselves believe they are polite, believers in "fair play", and more restrained in their emotions than other nations (Fox, 2005). The English associate England with its green fields, its hedgerows and villages with

\footnotetext{
${ }^{4}$ For the American view of England, see any episode of The Simpsons that involves visits to England or visitors from England; for the funniest French stereotypes of Englishness, see the comic book Asterix ches les Bretons (Goscinny \& Uderzo, 1966).
} 
church towers, pubs that serve real (bitter) $\mathrm{ale}^{5}$ and cricket pitches, all representing a bucolic version of the past. England is an imagined community (Anderson, 1990), and Englishness is defined by symbolic boundaries (Cohen, 1985) and invented traditions (Hobsbawm and Ranger, 1983). Invented traditions are the myths and stories that nation-states (and other imagined communities) tell about their histories, which create both belonging and exclusion. So folk traditions can be invented or (re) constructed because they are ways in which ruling elites can create a sense of national identity (Anderson, 1990). But folk traditions might also be residual, cultural traditions that sit outside the power structures of the elite (Kolb, 2013). Where they do, there is more freedom for those involved in those folk traditions to negotiate and re-shape symbolic boundaries, to allow different classes or genders to participate in them, for example. Where this takes place, symbolic community becomes like an onion, with each layer of skin being a symbolic boundary allowing different levels of belonging. That is, there is a constant negotiation and construction of symbolic boundaries, but with the ruling hegemonic elites having enormous power in defining what English people take to be England and Englishness.

Attempts to root Englishness, then, must be viewed as snapshots in time and any search for Englishness is, ultimately, futile. While Featherstone agrees with this argument, he points out that in England "nationalism remains the most significant cultural expression of social identity” (Featherstone, 2009, pp. 2-3). In considering nationalism, history points us to an Englishness that was seen as explicitly colonial and imperial, but with the decline of Great Britain as a world power this has been replaced by nostalgia for that past (Fox, 2005). As Great Britain has seen nationalism and national cultures emerge in Scotland and Wales, debates about England and its relationship to Great Britain have surfaced (Kumar, 2010). Mann (2011) suggests that "Englishness is more often accomplished through talking about people and ethnicity rather than through the use of geography”. In the wider English folk scene, Englishness, even when re-constructed and made more inclusive, is reliant on the discourse of ethnicity. Some people believe Britishness is a marker of cosmopolitanism and urbanism, and are fearful that celebrations of Englishness lead

\footnotetext{
5 'Real ale' is used to denote a type of beer that is shipped from the brewery to the pub with yeast in the barrel, giving it a short 'shelf life' but more flavour (Spracklen, Laurencic \& Kenyon, 2013). This along with other techniques in the brewery and the pub make British beer unique compared to the treated lager-type beers that dominate elsewhere.
} 
to racism and the exclusion of minority ethnic groups (Fox, 2005; Kumar, 2010; Mann, 2011; Uberoi \& Modood, 2012).

More central to debates about English national identity are the ideas of tradition and authenticity. In the first revival of English folk culture, morris dancing and folk music were seen as proper native English traditions about to be lost because of the rise of modernity (Francmanis, 2002). Morris and folk music became associated with elite concerns over racial purity (Boyes, 2010). The English folk scene as revived for the second time in the 1960s defended folk music and dance as authentic working-class folk traditions marginalized in commodified popular culture and elite culture (Boyes, 2010; Moore, 2002). In both revivals, the leisure activities became the sites of struggles over meaning and identity through debates over authenticity. Following Baudrillard (1988) it can be argued that the pre-existing experiences and the invented experiences become conflated and impossible to distinguish from one another, that "history [has become] instantaneous media memory without a past" (Baudrillard, 1988, p. 22), so the real experiences, while they may have happened, are indistinguishable from the invented tradition. We need to be concerned with the historical discourses in the present, and how they are used to create boundaries and cultural icons.

\section{Social Identity, Identity Work and the Cultural Web}

Roland Barthes' work on the creation of social identity through shared mythology is relevant here. Barthes (1972, 1977) described how a particular way of speaking, practising and acting (a discourse) can become a particularly modern mythology. He describes how a sign already formed within its own specific context (such as dancing or any other leisure practice) becomes a signifier for another sign (such as class, gender, locality, nationalism, sexuality, and "race”). It is this second sign that becomes attached the identity myth, which is normalized and historicized. The mechanics of this semiotics of myth are not important for this paper: what matters for our understanding of culture and community is that Barthes shows us how it is possible in modernity for social identity (meaning, belonging) to be formed through the use of myths and symbols in everyday activities (Hesmondhalgh, 2008). The key to social identity in leisure spaces and activities is the control of those spaces and activities. Modern sports and their myths and symbols, for example, can serve as sites where the gender order of hegemonic, heterosexual masculinity is reaffirmed, 
marginalizing those who do not conform to the proscribed gender roles (Pringle, Kay \& Jenkins, 2011). Outdoor leisure activities such as windsurfing or canoeing can be ways in which individuals reject the norms of society, but they can also be activities that depend on significant economic and cultural capital (Humberstone, 2011). Hence social identity, and expressions of dominant social groups in modern society, has become part of the study of leisure through discourses over meaning and the use of myths of belonging and exclusion to legitimize and support it.

Clifford Geertz provides us with a theory of social identity taken from cultural anthropology. Unlike Barthes, with his pessimistic view of the ability of humans to resist the symbolism of things and the dominant readings imposed on them, Geertz (1973) is optimistic about human agency. It is individual agency that leads people to create the social and cultural worlds that are around them, social identity is what we make of the symbols and structures others have put around us. As Geertz writes, "man is an animal suspended in webs of significance he has spun... [and the analysis of this] is not an experimental science in search of law but an interpretive one in search of meaning” (1973, p. 5). It is possible to be a folk music fan or morris dancer at any time in life, as a voluntary decision, and to be quickly accepted into the social networks associated with English folk or morris dancing, so long as you understand the meaning of the webs of significance that are internal to that particular English folk culture or scene. That is, you need to show you understand the mythologies, the knowledge, the controlled emotions, and the shared memories. In The Presentation of Self in Everyday Life (Goffman (1971) introduced a social psychological theory of identity: symbolic interactionism. This theory of social identity has been strongly influential in the social psychology of leisure and tourism, influencing the work of Stebbins on serious leisure and other forms of leisure (1982, 1997, 2009), Rojek on intentionality (2010) and MacCannell $(1973,1976)$ on authenticity and the tourist gaze. Goffman describes a world where our interactions with others are not necessarily authentic; in other words, we "role play" situations conforming to societal roles expected of us. A shared social reality therefore exists, and the social construction of reality and identity could be said to take place. In the leisure space of morris dancing, identity work is intentional and interactive, but bounded by the cultural webs woven by individuals and by the wider culture of the English folk scene. 
Some management studies scholars propose that organizations look to shape their culture in way that supports their strategic aims (Seel, 2000). Today, we see many companies telling the story of their business in an effort to attach some particular (traditional) attributes to their brand (Woodside, Sood \& Miller, 2007), while simultaneously aiming to boost sales or similar in the process. So, though traditions may grow somewhat organically to form webs of convenience, there are some who act to deliberately shape them for their own purpose. The cultural web framework is intended as a tool for organizations to identify and help shape a suitable organizational culture into a paradigm that meets their needs (Johnson, 1988; Seel, 2000). It reflects the work of Geertz (1973), Goffman (1971) and Cohen (1985) in drawing upon stories, symbols, rituals and routines. However, there are other elements that suggest that the paradigm of the organization aims not only to shape employee behaviour but influences all the stakeholders who are connected into the organisation. Such formal organization paradigms have power structures that are aimed at influencing the organization, control systems to manage inside and outside the organization and an organizational structure that draws these two together in an effort to achieve strategic aims. So, while the earlier analogy of an imaginary community as an onion and each onionskin being a symbolic boundary still hold, the existence of organizations aiming to control meaning and symbols in a purposeful way demonstrates that the boundaries of the onion layer are created by organizations as much as they are by individuals. One may even argue that a very powerful organization, such as the Morris Ring, acts to distort the organic growth of community.

If we return to ideas of Englishness and morris, they are held close together in through meanings related to local and national traditions, and intersecting issues such as gender, class and whiteness. Of course, they do not immediately sit together and form a consolidated view of meaning that would suggest, say, that the rituals and routines observed by Fox (2005) when looking at Englishness would be adopted by every fan of English folk music. On the other hand, English folk fans and morris dancers do love traditional real-ale, and folk music and morris dancing are frequently the main performances at real-ale festivals (Spracklen, Laurencic \& Kenyon, 2013). In essence, our view reflects Maffesoli (1996) and subsequent writers (Cova and Cova, 2002; Hesmondhalgh, 2008; Moore, 2002) who suggest that our world is now far more tribal and consisting of communities that individuals may move in and out 
of, or indeed, simultaneously belong to. Nuttall, Arnold, Carless, Crockford, Finnamore, Frazier and Hill (2011) have already attempted to use this idea to consider different types of music consuming communities. Not only is there a tension looking for communities to form but one that also pulls them apart as individuals move in and out of communities.

\section{Methodology}

\section{Rationale and Approach}

The study used qualitative methods. As part of a bigger research project on English folk, leisure and identity we interviewed individuals from two groups within the English folk scene professional folk musicians and morris dancers. In this paper we use the data generated by interviews with thirteen morris dancers (two of whom are also musicians for morris sides), along with our own knowledge and experience of the morris scene. The interviews were semi-structured and qualitative in nature, allowing us to explore the issues, answer our aims and provide a deep understanding of the cultural webs weaved through the English folk scene by the people to whom we spoke. Our decision to use qualitative methods was grounded in our theoretical concerns with symbolic meaning and the construction of identity and community. All these depend on communication and reflection. We were interested in how meaning and identity was expressed through our participants' stories and their beliefs about the folk scene. Epistemologically, our use of qualitative methods allowed us to emulate Geertz (1973) in developing 'thick’ accounts of our participants' leisure lives.

At first we suspected the professional musicians and the morris dancers would share sufficient backgrounds and opinions to allow us to combine the two groups into one analysis of the English folk scene as one imagined community, but as we progressed with both sets of interviews we realised they were sufficiently different to warrant separate analyses and discussion. We undertook pilot interviews with one professional folk musician and one morris dancer to refine the interview schedule using participants identified through our existing networks and contacts.

The theoretical underpinning of the methodology is naturalistic and inductive (Lincoln \& Guba, 1985), following Glaser and Strauss (1967) in their grounded theory approach, but allowing ourselves to be aware of the limits of our study and the aims of our study (Spracklen, 2013b). The literature review provided the basic structure of a set of themes used in the interviews, but we did not limit ourselves to 
that structure - where respondents discussed new issues we responded to them and modified our interview schedule.

\section{Positionality}

Neither of us is a morris dancer. However, the lead author of this paper has spent six seasons going to folk festivals and morris events, and has been out with three of the sides all-female tribal bellydance/folk dance tribe the 400 Roses (which included his wife, and in which he held the role of standard bearer). The 400 Roses started out as primarily an indoor dancing tribe, but through word-of-mouth and the efforts of some of the dancers they found themselves invited to dance with morris sides. It was at the point when the tribe had a regular season of summer morris events that the lead author volunteered to hold the tribe's standard and stand next to the musicians. The second author has been involved in promoting folk music gigs and events for many years. Both of us know and appreciate English folk music and consider ourselves to be English folk music fans. This insider status allows us to use our experience and knowledge of the scene to develop our theoretical framework and make sense of the data. But we do not identify with morris so much that we lose our ability as critical leisure scholars to understand the ways in which morris constrains as well as constructs identity and belonging.

\section{Sample}

Thirteen morris dancers/musicians were interviewed from five different morris sides, all based in the north of England. We recruited respondents from sides based in big cities and in small towns and suburbs, and across sides dancing different styles. As morris dancing is predominantly male four of the morris sides represented were allmale: the fifth was all-female, to ensure we tried to strike a balance that exists in 'the morris'. That said, we interviewed one woman musician in one of the male sides, so we had four female respondents alongside nine men. All the respondents were white and identified themselves as English. We interviewed across a range of adult ages. We recruited through initial contact with key individuals in the sides through websites and personal contacts. All the respondents' names and personal information has been 
redacted or pseudonymised in accordance with good ethical practice ${ }^{6}$. To aid the reader and to maintain confidentiality, we have given fake names to the morris sides: Bordley $^{7}$ Morris Men from a large city; Bordley Women; Netherton Morris from a small town; Totherton Morris from another town; and Greenville Morris Men from a suburb close to a tourist area.

\section{Data Collection}

The interview schedule developed three categories of questions. The first category was biographical, allowing us to understand the life-stories of the participants and their entry into morris dancing. The second category was relational, their connections in the cultural web of the English folk scene and their understanding of that scene (for example, whether they listened to English folk music). The third category was positional, finding out their opinions about what morris represented, who could be a morris dancer and what the future held for morris dancing.

Interviews took place over a period of six months. Participants were interviewed either in a quiet room of a pub, the spare room of a village hall on the evening dancers were having training sessions, or in one of the university's coffee bars. All interviews were undertaken by the lead author, with the second author sitting in on the first session. Interviews lasted between twenty minutes and ninety minutes. All the interviews were recorded and saved as .mp3 files.

\section{Data Analysis}

We analysed the interview data using the technique of Discourse Tracing (LeGreco and Tracy, 2009), identifying similarities in the uses of language, symbols, myths and meanings. This method of analysis lends itself well to exploring identity and belonging in cultural webs (Spracklen, 2013b). Our own expert knowledge and experience of the English folk scene and invested interest as fans, participants and observers, allowed us to feel confident that the data set was credible and its analysis reliable. We then used our theoretical framework and grounded-theory as an approach to develop codes through a constant comparative method. The coding was repeated

\footnotetext{
${ }^{6}$ First names have been created using the letters $A$ to $M$, which correspond to the order of in which information from interviews has been added to the analytical framework. The names used are taken from pop, rock and jazz singers.

${ }^{7}$ In reality, Bordley is a tiny farming hamlet in a remote part of the Yorkshire Dales; Netherton and Totherton are jokes; and Greenville is a description that could apply to anywhere on the edge of somewhere.
} 
and refreshed as we went through each transcript. This led to the six analytical themes used in the findings.

\section{Findings}

We present the findings of the research in the six themes that emerged from the analysis. These themes intersect with one another but are sufficiently distinctive. The themes are: becoming morris; morris as community; morris as culture and English tradition; keeping the past alive and (re)inventing the English past; Morris and the wider English folk scene; and belonging, Englishness, class and gender.

\section{Becoming Morris}

There was no clear pattern to account for becoming involved in morris across the lives of the respondents. Some of the respondents saw their involvement in morris as almost accidental - it just so happened that they had a teacher at school who set up a morris side (George from Totherton), or they moved to a street where the Squire ${ }^{8}$ of a morris side lived (Leo from Netherton), or they saw a morris side dancing and thought it looked interesting (Kurt from Bordley, and Isla from Bordley Women). Michael from Bordley explained his epiphany:

I just saw Bordley performing, and I thought yes, I'd love to have a go at that, I'd always wanted to do something active but had never quite done anything... I spoke to them afterwards and that's it.

Three of the morris dancers we spoke to were dancing because they were following in their father's footsteps. Aaron from Totherton Morris started out dancing Cotswold morris in a village side in the south-west of England, and danced through his teenage years and at university up north, where he joined Totherton. Billy joined Netherton because his father was the Squire and he thought it was a nice thing to do. Chris first danced with his father's morris side in Kent before coming north (again, for university) where he joined Bordley. Billy mentioned he had started dancing for Netherton with his brother, but that brother had dropped out as they had become older teenagers, "because he got interested in other things”. Aaron noted that he had got "some flack" from school friends for dancing morris but that had never put him off.

\footnotetext{
${ }^{8}$ The Squire is the leader of a morris side.
} 
The other respondents in the research became interested in morris as adults, such as Frank from Netherton, who went along with a friend when he moved to the town. For Debbie from Bordley Women, morris dancing was an extension of her interest in neo-paganism; but for her colleague Ella getting involved in morris dancing happened because she just happened to see a performance by Bordley Women - and the thought of women dancing together in a North-West style appealed to her interest in folk dancing at local folk clubs. Janice from Netherton was also interested in folk music and the folk scene as a musician, which led her to see a natural role for her as a musician in the side. Greenville Morris, according to Harry, was set-up one night by a group of men in the local pub (which included him) who were looking to do something active, sociable and fun to replace the football they were becoming too old to play. Becoming a morris dancer for him and his mates was "a bet, really... it was a bit of a laugh, never expected it to be serious”.

\section{Morris as Community}

All the respondents identified very strongly with their particular sides and the wider morris community or scene. For most of them, morris dancing was a chance to socialise and enjoy a sense of belonging. Frank from Netherton explained that "morris does bring people together”, and Harry from Greenville said “it’s a chance to get out, to meet people... you make friends for life in different sides”. There is, then, a sense of community within the sides: small groups of men and women training together, dancing together, going out to dances around the country, dancing in front of friends, family and neighbours. This sense of belonging is sealed through drinking, socializing away from morris and the reliance on others within the side (dancers and musicians). There were friendships and relationships between people at Bordley, Totherton and Bordley Women, and relationships were noted between male dancers and female musicians at Netherton and Greenville. In this morris is similar to any other semiformal leisure activity, with its membership organizations (the traditionally-minded Morris Ring and the more recent Morris Federation), private clubs and reliance on volunteers to keep things going. Some of the respondents we interviewed danced with other sides, often ones with different styles or sides that danced different folk styles (sword dancing, for example, or clogging), though Aaron danced Cotswold with three sides altogether (principally with Totherton, but also with Grenville and with his father's side back home). 
Morris sides represent localities and regional style, but the most important sense of community came from the wider morris scene: Aaron and Chris, despite being in different sides, were closely involved in a national campaigning organization for younger morris dancers, spending time getting dancers aged 18-30 together for drinking and dancing sessions; George volunteered at a national summer camp for morris dancers where he taught a number of workshops about certain traditions; and all the respondents valued weekends and days when they travelled to dance with other sides. Most morris sides travel up and down the country every summer, going to places where they have been invited by other sides. As Isla said, "it's a big part of what we do... it's about hosting others when they've invited you". Bordley traditionally have a day of dancing up in the Yorkshire Dales, as do Netherton, who travel out from their home town in an old London bus filled with their members and the sides they invite along for the day. Greenville have regular days in a tourist village close to their home locality, where they are regularly filmed by steam-train enthusiasts and foreign tourists. Bordley Women dance on the top of a hill on the edge of the city to welcome the dawn at the start of spring. All these occasions are evidence of the community belonging internal to the sides and internal to morris more widely. All the respondents feel that the cycle of training and performing, inviting and travelling, makes them feel a part of something solid.

\section{Morris as Culture and English Tradition}

All of the respondents felt that morris was a legitimate part of English culture, as folk culture, or as popular culture. Some of the respondents believed that morris was an important past of England's traditional folk culture. Billy said that it was "important to keep this tradition going because it's part of what made this country”. Janice explained how morris dancing is "about that connection going, the folk traditions that are ours”. However, all the respondents recognised that morris dancing had a strange and contested position within English culture. Firstly, as many of the respondents pointed out, it was an English tradition that was not part of the dominant culture, and not, as George put it, “something fashionable or modern”. Morris dancing is part of Englishness but it is not part of the cultural hegemony of the ruling classes, nor is it part of the postmodern popular culture of modern Britain.

All our respondents believed that it was important to keep morris dancing going because it was part of something traditional, something passed down from 
generation to generation. If there is doubt about how far back morris dancing goes as an "authentic" English tradition (see below), it is seen by all our respondents as a vital modern English tradition, rooted in their social lives and in their cultural web. It is a tradition played out year-on-year, bounded by a sense of space, carnival and seasonality - as Michael said, “it's become a tradition”. Some of them were concerned that with the rapid changes to leisure and culture in modern Britain, morris dancing might be threatened. Harry was concerned that Greenville Morris Men might not raise enough members to dance out in 2013, and Leo recognised that Netherton's ageing demographic meant “if we don’t get new men joining us, younger ones, we're in trouble”. However, most of the respondents believed morris could continue to attract new dancers (people who would be interested in preserving this English tradition) - and could adapt to the challenges of postmodernity and globalization because it was a constantly evolving tradition.

\section{Keeping the Past Alive: Re-inventing the (English) Past}

All the respondents noted the importance of tradition and morris dancing as a tradition. However, there were varying degrees of commitment to the notion that morris dancing is an authentic folk ritual, correctly recorded by folklorists such a Cecil Sharp (Boyes, 2010). For some of the respondents, the dances preserved in Sharp's books and handed down in material published by the Morris Ring were just an accident of what Sharp recorded on his travels: as Harry suggested, "no one really knows what else was going on”. There was some scepticism about authenticity, that the dances and the tunes and the costumes were an authentic reproduction of morris from some unspecified rural English past. Aaron said morris:

Must have changed all the time before it got recorded... what we've got is what was being danced just before it all died out... what was saved, but there is something in it.

Debbie was also sceptical of the authenticity of the morris tradition, but for her the tradition reflected a truth about England's pagan roots: "it is celebrating the seasons, old ways invented but still real”. Most of the respondents were comfortable with the idea that the steps and the tunes might evolve and change within the framework of the morris styles, only George expressed a desire to try to keep "the tradition going as it was danced years ago". Netherton Morris had created their own tunes and dances in the North-West style, and these had become their own tradition in 
the same way their unique costumes had become something of their own. What was clear was that most of the respondents wished to celebrate and recognise this idea of a more pre-modern English past wrapped up in morris, but they were happy to acknowledge the ways in which, as Chris suggested, "morris must change and does change”. So, for example, Isla was happy that Bordley Women were dancing steps she associated with the industrial north of the recent past, but she did not wish to see that past “re-created because you can't... it’s gone”.

\section{Morris and the wider English Folk scene}

Despite our original prediction that morris dancers would be active fans of English folk music, we found that the cultural web was weak between our respondents and the folk music scene. Most of the respondents did not identify folk music as something that attracted then to morris, nor did the majority of the dancers actively engage in the folk music scene, despite dancing to traditional tunes from the English folk repertoire. The respondents generally mentioned listening to the occasional CD or liking a particular tune they danced to, but could not identify contemporary English folk bands or musicians that they particularly liked. Where the respondents had been with their morris side to a folk festival such as Whitby, they expressed an enjoyment of the time spent listening to bands or singing sessions in pubs, but for these temporary moments of being in folk music spaces did not transform them into folk music fans. They did appreciate other forms of English folk dancing, and traditions such as mummering, well-dressing and rush-bearing, but they were not primarily defenders of English folk music as a market of a supposedly authentic, English folk identity.

There were, however, a number of the respondents who did demonstrate a connection in the cultural web between morris and folk music. Isla had arrived at morris dancing because she was a folk music fan in her youth, attending folk music clubs. Janice as a musician liked playing folk music and would play for other sides. Debbie was in a folk band and went to a singing night at a pub. For these three respondents there were varying degrees of connectivity but all had been involved in folk music before becoming involved in morris. For Frank, the direction was the other way round. He was a rock fan who had got interested in folk music after he had become a morris dancer - and now he plays in a band and puts on gigs for contemporary, professional English folk acts. For Frank at least there is an attraction to the aesthetic qualities of English folk music, as well as what that music represents: 
"I like the way the tradition is changing, becoming fashionable... it is more rooted than your average pop singer stuff”.

\section{Belonging, Englishness, Class and Gender}

For all the respondents, there was a strong sense of belonging to their side and the wider morris scene. The respondents also reflected on the way their sides represented their particular localities and the wider counties, regions and imagined nation of England. Frank from Netherton argued that they had to keep things such as dances and rituals played out in local villages because they were part of "local communities coming together”. Isla argued that her women danced a style that reflected the northern, working-class communities that flourished in the age of industry. Greenville Morris were a group of working-class northern men, who had come together as mates to dance. However, the other respondents were from a range of social backgrounds: for each respondent who was fixed in their upbringing as a working-class northerner there were southerners who had come up north for university or to work in a professional, salaried position.

For Chris from Bordley, it was important to maintain morris dancing as part of a wider "cultural heritage of this country", a view reflected by George from Totherton, Harry from Greenville and Billy from Netherton. All the respondents were white, and observation of morris sides in the north of England suggests nearly all morris sides (dancers and musicians) are white, even where sides are based in multicultural urban places such as Bordley and Netherton. When we asked the respondents to consider whether morris might be unwelcoming to outsiders, we suggested to two-thirds of the respondents to consider whether it might be possible for a Japanese student at a university to be able to "fit in" to their morris side. The respondents all told us that morris was inclusive, but they did recognise that such a scenario might be unrealistic. As Harry suggested, “it isn’t fashionable, so it's not going to be attractive to many people anyway”. Debbie was aware of the attraction of the English folk scene to far-right ideologues looking to get support for their racism from people who are interested in English traditions. She told us "there have been some people in the scene who've supported that”. However, she did not believe this represented the morris scene at all, a view echoed by all the respondents who considered the tension between morris and modern, urban lifestyles and spaces. 
The Morris Ring has been critical of women becoming morris dancers or musicians, and has ruled in the past that sides affiliated to it must not have female dancers dancing alongside men (the Ring said it was happy for all-women sides to exist at the end of the twentieth century). For the Ring, maintaining the tradition means maintaining morris as a predominantly male practice. Most of our respondents were highly critical of the Ring's position, though George noted he preferred to see all-male sides and Chris said he understood why the Ring might try to protect the tradition from being changed too much. Michael did not see why Bordley would consider allowing women to dance with them, as "there's the Ladies side for them". The practice of the local morris scene remains dominated by male sides, and where women are involved they are musicians or are in the all-women sides that exist in smaller numbers.

\section{Discussion}

In the cultural web of Englishness, morris is one part of a wider folk scene, and one part of a wider imagining of nation and national identity (Anderson, 1990). As identified earlier, the turn in the West to folk as national history and culture in the late nineteenth-century was related to questions of legitimacy and loss. The seekers of folk music and folk dances wanted to find a national folk culture pure and untouched by the evils of modernity at a time when rural communities were shrinking and industrialization was growing. So Cecil Sharp found healthy English men in villages dancing morris, and ensured morris dancing was transmitted as a male activity. In the second half of the twentieth century, folk music and dance came to be seen as an authentic alternative culture, a leisure space and leisure activity of resistance to the ruling hegemonies of the Western world. So the English folk scene is founded on nationalism, the search for authenticity, and a protest about capitalism and the ruling order. Morris today has some of all of these ideologies in its own cultural web, as evidenced by our research. For the respondents, morris is something that is part of a tradition, part of the English national story and identity - but like the dancers in Irving and Giles' (2011) research, our morris dancers see the dance also as a place of resistance and challenge, subverting and transgressing the social order of the twentyfirst century. Morris dancing is not cool, and it is not something done by the ruling elites. It remains a marginal leisure activity where individuals can perform in a Goffmanesque sense their own sense of belonging and Englishness. Morris dancing 
becomes a leisure site for the construction of identity through a number of contestations and negotiations. Following Geertz (1973) we might say that the morris dancers are free to construct their social identities so far as the cultures and society that surround them allows them the freedom to act.

Morris is, however, a communicative leisure form, a space and activity in which individuals use their agency to perform a range of social identities. Morris is unfashionable and perhaps anti-modern, and the individuals in our research were keen to identify with the narratives of authenticity that surround the cultural web of English folk: if their initial interest in morris was accidental or through familial connection, all the respondents have maintained a deep cultural bond with the scene. Stormann (2010) states that choices in cultural recreation define people's humanity - this is what Spracklen (2011) suggests is the communicative purpose of leisure. Being morris is what the respondents in our research do, what they are. They perform a love of tradition even if they know the traditions are subject to change and subject to historical criticism (Boyes, 2010; Francmanis, 2002). They take part in this activity as a form of serious leisure (Stebbins, 1982, 2009): training hard, spending their own money, spending summer weekends away from home, turning to playing music or running the finances of the sides. The rewards for this commitment come in the friendships and relationships they have forged, the drinks in the pub after a dance-out, and the satisfaction they are doing something meaningful with their leisure lives. The wider cultural web created in the English folk scene establishes an organizational structure and culture to which they differently feel a sense of belonging and attachment. They are involved in building an English past, in an English present, but they are not interested in keeping a narrow, ethnic Englishness pure from the changes of multicultural Britain. They might be wary of the impact of modernity and globalization but for the respondents morris and English folk traditions are as important as the folk traditions of any culture, and should be recognised as authentic parts of the history and narrative of the nation.

\section{Conclusion}

In this paper, we have shown how identity work in the leisure space of morris dancing creates Englishness - and other identities such as gender and class - through the struggle to define belonging in the Geertzian webs of significance. The struggle is that between those of high status and power, the cultural elites of England, and those who 
remain marginalized. We have explored how English morris dancers negotiate meaning and community in morris dancing through the use of communicative agency to create morris dancing as communicative leisure space. We have shown how the construction and contestation of Englishness expressed in morris dancing is within the context of the cultural web (Seel, 2000), which draws on the work of Geertz (1973) and Goffman (1971). We have used this model to understand how morris dancers see their role as dancers and leisure agents in consciously defending versions of Englishness, English traditions and inventions, the practices and traditions of folk and morris, and the various symbolic communities they inhabit. The communicative nature of the morris leisure space allows it to have the potential to be transformative on individual lifestyle choices and leisured identities, but morris is potentially exclusionary if used to construct and legitimize monocultural versions of Englishness. 


\section{References}

Anderson, B. (1990). Imagined communities. London: Verso.

Baudrillard, J. (1988). Selected writings. Cambridge: Polity.

Boyes, G. (2010). The imagined village: Culture, ideology and the English folk revival. No Masters Co-Operative Limited: Leeds.

Cohen, A.P. (1985). The symbolic construction of community. London: Tavistock.

Condron, S. (2011). Unlikely anarchists: Morris-dancing 'flash mobs' to protest against Olympics snub... but won't we hear them coming with all those bells? Daily Mail. Retrieved from http://www.dailymail.co.uk/news/article2072583/Unlikely-anarchists-Morris-dancing-flash-mobs-protest-Olympicssnub.html\#ixzz1gE516f9u.

Cova, B., \& Cova, V. (2002). Tribal marketing: The tribalisation of society and its impact on the conduct of marketing. European Journal of Marketing, 36, 595620.

Critcher, C. (2000). ‘Still raving’: Social reaction to Ecstasy. Leisure Studies, 19, 145162.

Dudrah, R. (2011). British bhangra music as soundscapes of the Midlands. Midland History, 36, 278-291.

Featherstone, S. (2009). Englishness: Twentieth century popular culture and the forming of English identity. Edinburgh: Edinburgh University Press.

Fox, K. (2005). Watching the English: The hidden rules of English behaviour. London: Hodder and Stoughton.

Francmanis, J. (2002). National music to national redeemer: The consolidation of a 'folk-song' construct in Edwardian England. Popular Music, 21, 1-25.

Frazer, J. (2004[1890]). The golden bough: A study in magic and religion. Cambridge: Cambridge University Press.

Geertz, C. (1973). The interpretation of cultures. New York: Basic.

Glaser, B., \& Strauss, A. (1967). The discovery of grounded theory. Chicago: Aldine.

Goffman, E. (1971). The presentation of self in everyday life. Harmondsworth: Penguin.

Goscinny, R., \& Uderzo, A. (1966). Asterix chez les Bretons. Paris: Dargaud.

Habermas, J. (1981). The theory of communicative action. Cambridge: Polity.

Hesmondhalgh, D. (2008). Towards a critical understanding of music, emotion and self-identity. Consumption, Markets and Culture, 11, 329-343. 
Hobsbawm, E., \& Ranger, T. (Eds.). (1983). The invention of tradition. Cambridge: Cambridge University Press.

Humberstone, B. (2011). Embodiment and social and environmental action in naturebased sport: Spiritual spaces. Leisure Studies, 30, 495-512.

Hutton, R. (2006). Witches, druids and King Arthur. Winchester: Hambledon Continuum.

Irving, H.R., \& Giles, A.R. (2011). A dance revolution? Responding to dominant discourses in contemporary integrated dance. Leisure/Loisir, 35, 371-389.

Jaimangal-Jones, D., Pritchard, A., \& Morgan, N. (2010). Going the distance: Locating journey, liminality and rites of passage in dance music experiences. Leisure Studies, 29, 253-268.

Jefferies, M., \& Tyldesley, M. (Eds.). (2011). Rolf Gardiner: Folk, nature and culture in interwar Britain. Farnham: Ashgate.

Johnson, G. (1988). Rethinking incrementalism. Strategic Management Journal, 9, 75-91.

Kolb, A. (2013). The migration and globalization of schuhplattler dance: A sociological analysis. Cultural Sociology, 7, 39-55.

Kumar, K. (2010) Negotiating English identity: Englishness, Britishness and the future of the United Kingdom. Nations and Nationalism, 16, 469-487.

Lefebvre, H. (1991[1947]). Critique of everyday life. London: Verso.

LeGreco, M., \& Tracy, S. (2009). Discourse tracing as qualitative practice. Qualitative Inquiry, 15, 1516-1543.

Lenskyj, H. (2000). Inside the Olympic industry: Power, politics, and activism. Albany: SUNY Press.

Lincoln, Y., \& Guba, E. (1985). Naturalistic inquiry. London: Sage.

MacCannell, D. (1973). Staged authenticity: Arrangements of social space in tourist settings. American Journal of Sociology, 79, 589-603.

MacCannell, D. (1976). The tourist: A new theory of the leisure class. New York: Schoken Books.

Maffesoli, M. (1996). The time of the tribes: The decline of individualism in mass society. London: Sage.

Mann, R. (2011). “It just feels English rather than multicultural”: Local interpretations of Englishness and non-Englishness. Sociological Review, 59, 109-128.

Moore, A. (2002). Authenticity as authentication. Popular Music, 21, 209-223. 
Nuttall, P., Arnold, S., Carless, L., Crockford, L., Finnamore, K., Frazier, R., \& Hill, A. (2011). Understanding music consumption through a tribal lens. Journal of Retailing and Consumer Services, 18, 152-159.

Pringle, R., Kay, T., \& Jenkins, J.M. (2011). Masculinities, gender relations and leisure studies: Are we there yet? Annals of Leisure Research, 14, 107-119.

Rojek, C. (2010). The labour of leisure. London: Sage.

Seel, R. (2000). Culture and complexity: New insights on organisational change. Organisations and People, 7, 2-9.

Spracklen, K. (2009). The meaning and purpose of leisure: Habermas and leisure at the end of modernity. Basingstoke: Palgrave Macmillan.

Spracklen, K. (2011). Constructing leisure: Historical and philosophical debates. Basingstoke: Palgrave Macmillan.

Spracklen, K. (2013a). Whiteness and leisure. Basingstoke: Palgrave Macmillan.

Spracklen, K. (2013b). Nazi punks folk off: Leisure, nationalism, cultural identity and the consumption of metal and folk music. Leisure Studies, 32, 415-428.

Spracklen, K., Laurencic, J., \& Kenyon, A. (2013). “Mine’s a pint of bitter”: Performativity, gender, class and representations of authenticity in real-ale tourism. Tourist Studies, published ahead of print at DOI:10.1177/1468797613498165.

Stebbins, R. (1982). Serious Leisure: A conceptual statement. Pacific Sociological Review, 25, 251-272.

Stebbins, R. (1997) Casual leisure: A conceptual statement. Leisure Studies, 16, 1725.

Stebbins, R. (2009). Leisure and consumption. Basingstoke: Palgrave Macmillan.

Stormann, W.F. (2010). Cultural recreations and hierarchy: A historical interplay. Leisure/Loisir, 34, 223-241.

Turner, V. (1969). The ritual process: Structure and anti-structure. Ithaca: Cornell University Press.

Uberoi, V., \& Modood, T. (2012). Inclusive Britishness: A multiculturalist advance. Political Studies, 61, 23-41.

Urquia, N. (2005). The re-branding of salsa in London's dance clubs: How an ethnicised form of cultural capital was institutionalised. Leisure Studies, 24, 385-397.

Williams, R. (1981). Culture. London: Fontana. 
Woodside, A.G., Sood, S., \& Miller, K. (2007). When consumers and brands talk: Storytelling theory and research in consumer psychology and marketing. Psychology and Marketing, 25, 97-145. 